\title{
Contribution of tiller age category to herbage accumulation of Marandu palisadegrass under two fertilization regimes
}

\section{Contribuição da categoria de idade do perfilho para o acúmulo de forragem de capim-marandu sob dois regimes de fertilização}

\begin{abstract}
Manoel Eduardo Rozalino Santos ${ }^{1 *}$; Angélica Nunes de Carvalho ${ }^{2}$; Adenilson José Paiva3; Bruno Humberto Rezende Carvalho4; Gustavo Segatto Borges5; Simone Pedro da Silva6; Davi Moraes Oliveira7; Dallety Haloma Alves Miler de Oliveira7
\end{abstract}

\section{Highlights}

The proportion of young tillers were higher in late spring and summer.

Old tiller has high contribution to growth and senescence rates.

Nitrogen and phosphate fertilization increases tiller number and forage production.

\begin{abstract}
Based on the hypothesis that climate and fertilizers influence the proportion of tiller age categories in the canopy and, consequently, in herbage accumulation, the objective of this study was to determine the population density and the contribution of tiller age categories for herbage accumulation of Urochloa brizantha cv. Marandu during the year and in response to phosphate and nitrogen fertilization. The treatments consisted of two fertilization strategies: low and high fertilization and three tiller ages (young, mature and old), evaluated at four times of the year: winter, early and late spring, and summer. The total number of tillers and the proportion of young tillers were higher in late spring and summer. The growth and herbage accumulation rates showed a typical seasonal pattern and were higher in the canopy under high fertilization. Old tillers

1 Prof. Dr., Postgraduate Program in Veterinary Science, PPGCVET, Universidade Federal de Uberlândia, UFU, Uberlândia, MG, Brazil. E-mail: manoel.rozalino@ufu.br

2 M.e in Veterinary Science, UFU, Uberlândia, MG, Brazil. E-mail: angelicanunescoro@hotmail.com

3 Prof. Dr., Institute of Animal Science, Universidade Federal Rural do Rio de Janeiro, UFRRJ, Seropédica, RJ, Brazil. E-mail: ajpaiva@ufrrj.br

4 Student of the Doctoral Course in the Veterinary Science Postgraduate Program, PPGCVET, UFU, Uberlândia, MG, Brazil. E-mail: brunohrc16@hotmail.com

5 Student of the Master Course in the Veterinary Science Postgraduate Program, PPGCVET, UFU, Uberlândia, MG, Brazil. E-mail: gustavosegatto73@gmail.com

6 Profa Dra, UFU, Uberlândia, MG, Brazil. E-mail: simone.silva@ufu.br

7 Graduation Students in Animal Science, UFU, Uberlândia, MG, Brazil. E-mail: davi.oliveira@ufu.br; dallety.oliveira@ ufu.br

* Author for correspondence
\end{abstract}

Received: June 30, 2021 - Approved: Oct. 20, 2021 
contributed more to control the total stem growth rate, as well as the canopy senescence rate. The highest percentage of young tillers is related to the high herbage accumulation in the Marandu palisadegrass canopy. Key words: Brachiaria brizantha. Forage production. Nitrogen and phosphate fertilization. Tropical pasture. Urochloa brizantha.

\section{Resumo}

Levando em consideração que os fertilizantes e o clima podem influenciar na faixa etária de perfilhos de um dossel e consequentemente no acúmulo de forragem, o objetivo desse trabalho foi determinar a densidade populacional e a contruibuição das faixas etárias de perfilhos para o acúmulo de forragem Uruchloa brizanta cv Marandu durante o ano e em resposta a fertização com fosfato e nitrogênio. $O$ tratamento foi constituido de duas estratégias de fertilização: baixa e alta fertilização e três faixas etárias de perfilhos (jovem, maduro e velho) avaliadas em quatro épocas do ano (inverno, início e fim da primavera e verão). O número total de perfilhos e a proporção de perfilhos jovens foram maiores no final da primavera e no verão. As taxas de crescimento e de acumulação de forragem mostraram um padrão sazonal típico e foram maiores no dossel com alto nivel de fertilização do que com baixo nível de fertilizante. O perfilho velho contribuiu mais para controlar as taxas de crescimento total do caule, bem como para a taxa de senescência do dossel. A maior porcentagem de perfilhos jovens está relacionada ao alto acúmulo de forragem no dossel do capimmarandu.

Palavras-chave: Adubação nitrogenada e fosfatada. Brachiaria brizantha. Pastagem tropical. Produção de forragem. Urochloa brizantha.

\section{Introduction}

Growth consists of the production of new tissues in forage plants, while senescence corresponds to the remobilization and transfer of soluble constituents from mature to immature tissues, usually followed by chlorosis and subsequent death of mature tissues (Allen et al., 2011). With the balance between growth and senescence, which occur concurrently, it is possible to calculate pasture herbage accumulation (M. E. R. Santos, Fonseca, \& Gomes, 2013; Sousa et al., 2013; Pereira, Paiva, Geremia, \& Silva, 2013; Sousa et al., 2011). Herbage accumulation is influenced by the genetics of the forage plant (Lemaire \& Chapman, 1996), by the environment characteristics (Gastal \& Lemaire, 2015) and by pasture management (Gimenes et al., 2011). In this context, changes in availability of soil nutrients, as nitrogen (Fagundes et al., 2006) and phosphate (Patês et al., 2007) fertilization, as well as climatic variations throughout the year (Sbrissia, Schmitt, Duchini \& Silva, 2020), change the number and growth pattern of tillers, which interfere with herbage accumulation (Martins, Schmitt, Duchini, Miqueleto, \& Sbrissia, 2021).

The patterns of emergence and survival of tillers result in variations in the percentage of young, mature and old tillers in the pasture (M. E. R. Santos et al., 2018; Alves et al., 2019; M. E. R. Santos et al., 2020; A. N. D. Carvalho et al., 2019). Paiva et al. (2011), working with Marandu palisadegrass (Urochloa brizantha cv. Marandu) managed in continuous stocking and fertilized with nitrogen, found that, in fall and winter, pastures were composed mainly of old tillers, whereas in summer, the percentage 
of young tillers predominated. This response pattern was similar for all nitrogen rates evaluated, but the magnitude was higher in pastures fertilized with 300 and $450 \mathrm{~kg} \mathrm{~N} \mathrm{ha}^{-1}$ $\mathrm{N}$ compared to those not fertilized or fertilized with $150 \mathrm{~kg} \mathrm{~N} \mathrm{ha}{ }^{-1}$.

The growth and senescence patterns are different depending on the tiller age. Alves et al. (2019) reported that the leaf emergence and elongation rates were higher in young than old tillers of Marandu palisadegrass. This same pattern had already been reported by Barbosa et al. (2012) on Tanzania grass (Megathyrsus maximus cv. Tanzânia); Montagner et al. (2011) on mombaça grass (Megathyrsus maximus cv. Mombaça) during the summer; and Paiva et al. (2011) on Marandu palisadegrass. Thus, changes in the numbers of these tillers age categories have relevant implications for pasture herbage accumulation.

Marandu palisadegrass is, in Brazil, one of the most used forage grass and is widely researched. However, the contributions of young, mature and old tillers to growth, senescence and herbage accumulation rates in the fertilized canopy have not been quantified yet. So far, studies are conducted to quantify only the number (Paiva et al., 2011; M. E. R. Santos et al., 2020) and morphogenesis (Montagner et al., 2011; Paiva et al., 2011; Difante et al., 2011; Barbosa et al., 2012; D. R. G. Silva, Costa, Fraquin, Oliveira, \& Bernardes, 2013; Alves et al., 2019) of these tiller age categories during the seasons, including herbage accumulation at the level of the individual tiller, but not at the forage level in the Marandu palisadegrass canopy (plant population).

Based on the above, we hypothesized that: (i) the application of higher nitrogen and phosphorus doses increases the total number of tillers, the percentage of young tillers and herbage accumulation in the canopy; (ii) young tillers predominate in the canopy during spring and summer, while old tillers predominate in fall and winter; and (iii) the higher occurrence of young tillers in the canopy results in greater herbage accumulation in the canopy. Thus, the objectives of this study were to describe temporal variations in the population density of young, mature and old tillers in Marandu palisadegrass canopy subjected to fertilization and to determine the contribution of these tillers age categories to growth, senescence and herbage accumulation in the canopy.

\section{Material and Methods}

The experiment was conducted from March 2016 to March 2017, at the Capim Branco Experimental Farm, Federal University of Uberlândia, in Uberlândia, state of Minas Gerais (1853'19 "S, 48²0'57"W and $863 \mathrm{~m}$ a.s.l.). According to the Köppen classification, the climate of the region is Aw, tropical savanna (Alvares, Stape, Sentelhas, Gonçalves, \& Sparovek, 2013), with well-defined dry (April to September) and rainy (October to March) seasons, with annual average temperature and rainfall of $22.3^{\circ} \mathrm{C}$ and $1,584 \mathrm{~mm}$. The climatic data during the experimental period was obtained in a meteorological station located $200 \mathrm{~m}$ from the experimental site (Figure 1A). The average temperature and monthly rainfall were used to calculate the soil water balance (Thornthwaite \& Mather, 1955), considering a $50 \mathrm{~mm}$ soil water holding capacity (Figure 1B).

The soil in the experimental area was classified as Dystrophic Dark Red Latosol (H. G. Santos et al., 2006) and its chemical characteristics, at the 0 to $20 \mathrm{~cm}$ layer, on March 6, 2016 were: $\mathrm{pH}$ in $\mathrm{H}_{2} \mathrm{O}$ : 6.1; P: $4.6 \mathrm{mg}$ 
$\mathrm{dm}^{-3}$ (Mehlich-1); K: $100 \mathrm{mg} \mathrm{dm}^{-3} ; \mathrm{Ca}^{2+}: 5.1$ $\mathrm{cmol}_{\mathrm{c}} \mathrm{dm}^{-3} ; \mathrm{Mg}^{2+}: 2.1 \mathrm{cmol}_{\mathrm{c}} \mathrm{dm}^{-3} ; \mathrm{Al}^{3+}: 0 \mathrm{cmol}_{\mathrm{c}}$ $\mathrm{dm}^{-3}\left(\mathrm{KCl} 1 \mathrm{~mol} \mathrm{~L}^{-1}\right) ; \mathrm{H}+\mathrm{Al}: 2.9 \mathrm{cmol}_{\mathrm{c}} \mathrm{dm}^{-3} ; \mathrm{V}: 72 \%$ and organic matter: $5.05 \mathrm{dag} \mathrm{kg}^{-1}$. According to these characteristics, liming and potassium fertilization were not necessary.

The experimental area consisted of eight plots (experimental units) of $9 \mathrm{~m}^{2}$ each, in a pasture of Urochloa brizantha (Syn. Brachiaria brizantha) cv. Marandu planted in 2000 and with no signs of degradation. This was a randomized complete block experimental design, with four replications. Two fertilization strategies were evaluated during the year, one typical of a low technological system, called low fertilization condition; and the other, for a high technological system, called high fertilization condition. In the low fertilization condition, $25 \mathrm{~kg} \mathrm{P}_{2} \mathrm{O}_{5}$ ha-1 $^{-1}$ were applied in March and October 2016, and $50 \mathrm{~kg} \mathrm{~N} \mathrm{ha}^{-1}$ were applied only in December 2016. In the high fertilization condition, $50 \mathrm{~kg} \mathrm{P}_{2} \mathrm{O}_{5}$ ha $^{-1}$ were applied in March and October 2016, and $60 \mathrm{~kg} \mathrm{~N} \mathrm{ha}^{-1}$ were applied monthly during the rainy season, totaling $120 \mathrm{~kg} \mathrm{~N} \mathrm{ha}^{-1}$ from March to April 2016 and $300 \mathrm{~kg} \mathrm{~N} \mathrm{ha}^{-1}$ in the period from October 2016 to February 2017. Fertilizers were applied on the plots in the late afternoon. Urea was used as a nitrogen source and single superphosphate as a phosphorus source.

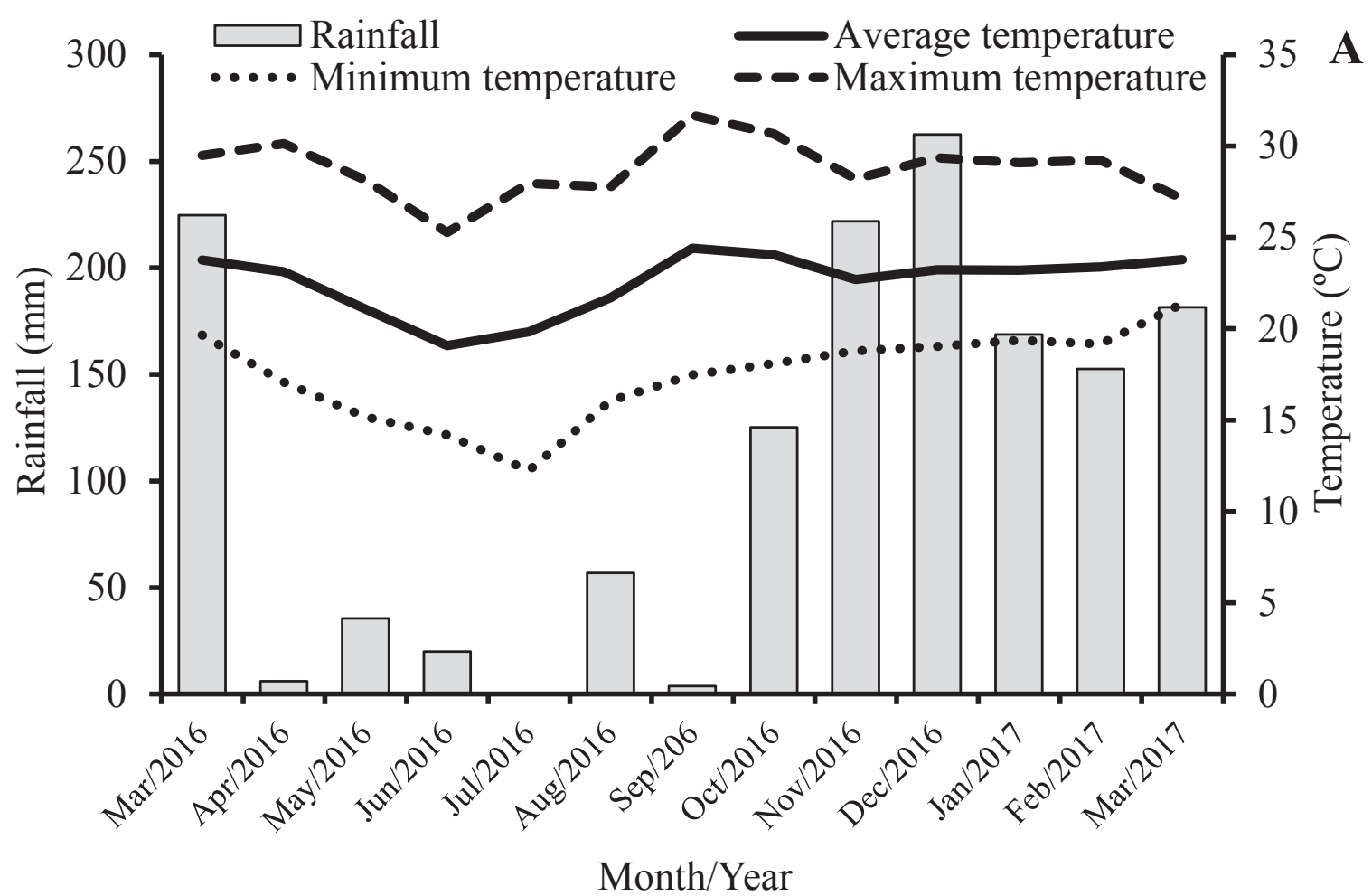

continue... 
continuation...

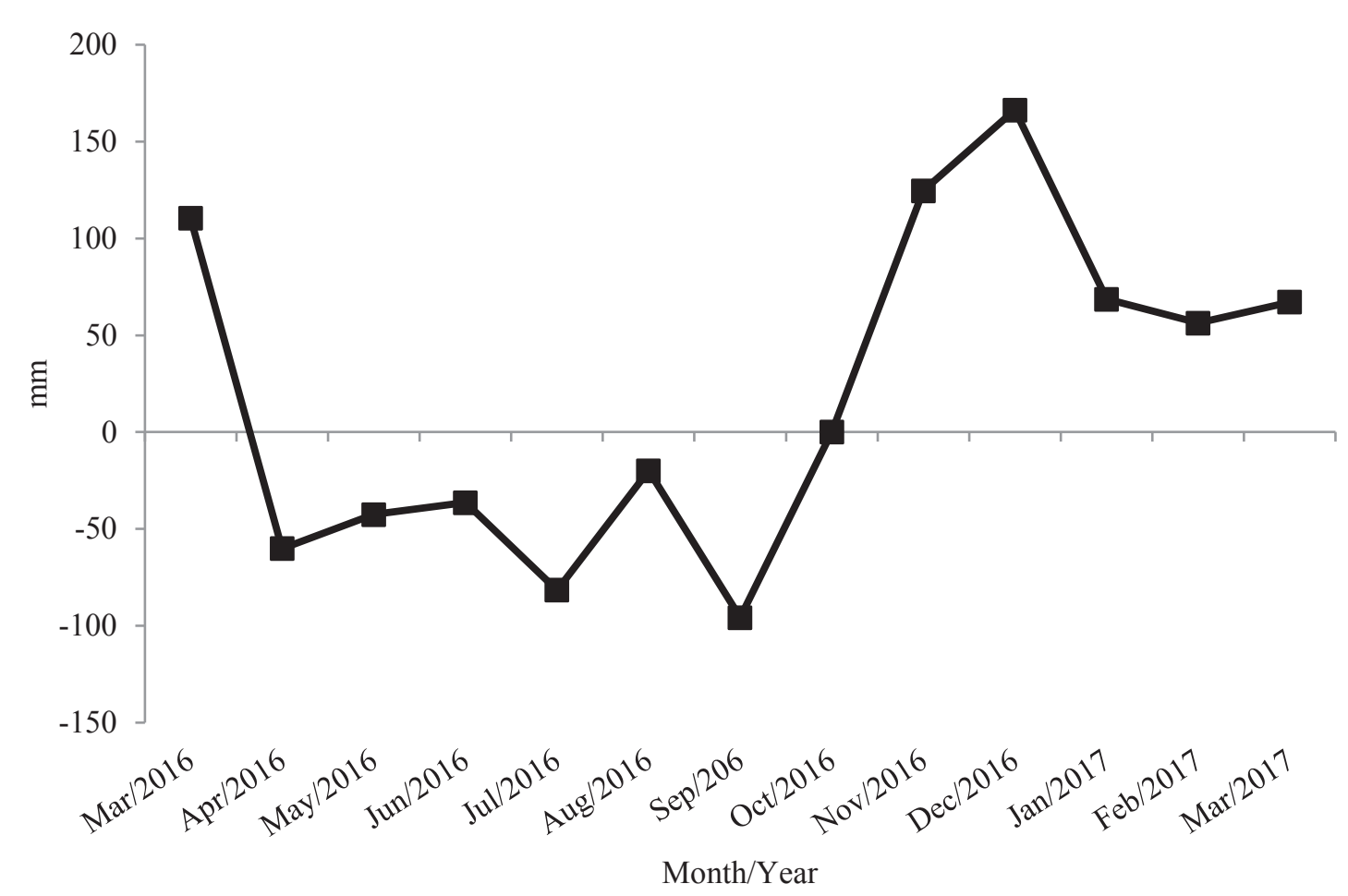

$\mathrm{B}$

Figure 1. Monthly climatic data $(A)$ and soil water balance $(B)$ during the experimental period in Uberlândia, state of Minas Gerais, Brazil.

In early March 2016, pasture was cut at $5 \mathrm{~cm}$ above the ground. Thereafter, canopies were maintained at a $15 \mathrm{~cm}$ steady state during fall and winter, and $30 \mathrm{~cm}$ during spring and summer, according to the recommendations of Costa et al. (2016) and M. E. R. Santos et al. (2017). In tropical pastures with a high leaf area index (LAl), the herbage accumulation is lower at times of the year under stressful abiotic factors (e.g. low temperature, drought and low incidence of light) (Sbrissia et al., 2020). To maximize herbage accumulation, the plant demands suitable temperature, water and solar radiation necessary to maintain the tiller population (Duchini, Guzatti, Echeverria, Américo, \& Sbrissia, 2018) and photosynthetic apparatus (Parsons \& Penning, 1988). Thus, higher defoliation intensity in fall and winter, compared to spring and summer, is necessary to maximize herbage accumulation (Sbrissia et al., 2020). For this reason, in our study, we adopted the seasonal defoliation management of Marandu palisadegrass $(15 \mathrm{~cm}$ in fall and winter and $30 \mathrm{~cm}$ in spring and summer), necessary to increase tillering in spring (Costa et al., 2016; Pessoa et al., 2016), to improve the sward structure (M. E. R. Santos et al., 2017) and forage production (Terra et al., 2020).

Canopy height was controlled at steady state by measurement once a week in fall and winter, and twice a week during spring and summer. Parts of the plants above the desired heights were cut with pruning shears and the excess forage removed from the plot. 
The fall months (March to June 2016) were considered as an adaptation period of plants to experimental management. Under research conditions, the occurrence of residual effects, due to variations in pasture management before the onset of the experiment, can interfere with responses of variables to be measured, leading to misunderstood. Thus, Silva, Sbrissia and Pereira (2015) recommend that it is necessary to carefully plan the experiments with forage plants, in order to ensure the adaptation of the pasture to the defoliation regime to be evaluated, before starting the period for measuring the response variables. Thus, the experimental results were grouped into: winter (July, August and September 2016), early spring (October 2016), late spring (November and December 2016) and summer (January, February and March 2017).

In March 2016, two $30 \mathrm{~cm}$ diameter PVC rings were attached to the soil of each plot. In these rings, the tiller population dynamics was evaluated (Sbrissia et al., 2010), until March 2017. With these data, the total number of tillers was calculated. From July 2016, the proportion of young (less than two months), mature (two to four months) and old (more than four months) tillers (Paiva, Pereira, Silva, \& Dias, 2015) in the canopy was determined. In our study, only basal tillers were considered, due to their predominance in canopies (97\% total number of tillers). With the evaluation of tiller population dynamics, it was possible to know the real age of all the tillers inside the rings. Thus, the transition from new tillers to mature and then old tillers was monthly controlled.

Herbage accumulation was calculated based on the morphogenetic assessment of individual tillers (Bircham \& Hodgson, 1983). In each of the two PVC rings per plot, two basal tillers of each age category were marked, a total of 12 tillers per plot. The leaf blade and stem lengths of these tillers were measured once a week in winter and twice a week in spring and summer. At each time of the year, new tillers were marked and evaluated for 30 days. This always occurred within the same evaluation ring. All tiller measurements were taken before the necessary cuts to maintain the height of the forage canopy. Positive variations in the length of leaf blades and stems were considered for the calculation of elongation rate of these components, while the negative variation in the green leaf blade length was used to calculate their senescence rate, that is, the senescence was estimated considering the yellowing or death of leaves.

Conversion factors were generated to express leaf growth and stem growth rates, as well as leaf senescence rate, in $\mathrm{kg} \mathrm{ha}^{-1}$ day of dry matter (DM). For this purpose, in the middle of each morphogenesis evaluation period, 50 tillers were collected close to the ground from each plot, separated into green leaf blades (expanding and expanded) and green stems and measured for length. These fractions were oven-dried at $55^{\circ} \mathrm{C}$ for 72 hours. After drying, morphological components were weighed and their masses divided by their respective total lengths. Thus, conversion factors were obtained, in $\mathrm{mg} \mathrm{cm}^{-1}$, and used to transform the values from $\mathrm{cm}^{\text {tiller }}{ }^{-1}$ day 1 to $\mathrm{mg} \mathrm{tiller}^{-1}$ day $^{-1}$. With the multiplication of the growth and senescence values of leaf and stem, expressed in mg tiller ${ }^{-1}$ day $^{-1}$, by the number of green tillers (tillers ha-1) in each plot, it was possible to obtain the leaf (LGR) and stem (SGR) growth rates, and the leaf senescence rate (LSR), in $\mathrm{kg} \mathrm{ha}^{-1}$ day $^{-1} \mathrm{DM}$. The conversion factors of expanding leaf blades, expanded leaf blades and stem were used to 
calculate LGR, LSR and SGR, respectively. The sum of the LGR and SGR corresponded to the total growth rate (TGR). Subtracting LSR from LGR and TGR, the leaf blade accumulation (LAR) and total accumulation (TAR) rates were obtained, respectively.

Analysis of variance was carried out in a completely randomized design using the PROC MIXED of SAS ${ }^{\circledR}$ (SAS Inst., Cary, NC, USA). The covariance matrix was selected using the Akaike Information Criterion (Wolfinger, 1993). The effects of fertilization condition, tiller age, time of the year and their interactions were considered fixed; and blocks, as a random effect. The time of year was considered repeated measures over time.
Only the variable "total number of basal tillers", as it is the sum of the numbers of all tiller categories, was analyzed without the tiller age effect. The means were compared by Tukey's test $(\mathrm{P}<0.05)$.

\section{Results and Discussion}

The number of basal tillers (NBT) was influenced by the time of the year, being higher $(\mathrm{P}<0.05)$ in late spring and summer, compared to winter and early spring (Table 1$)$. The NBT was also influenced $(P<0.05)$ by fertilization, with 756 and 906 tillers $\mathrm{m}^{-2}$ in canopies under low and high fertilization, respectively.

\section{Table 1}

Basal tiller $\mathrm{m}^{-2}$ and herbage accumulation rate ( $\mathrm{kg} \mathrm{ha}^{-1}$ day $\left.^{-1} \mathrm{DM}\right)$ of Marandu palisadegrass canopies in different times of the year

\begin{tabular}{|cccccc|}
\hline Characteristic & Winter & Early Spring & Late Spring & Summer & SEM \\
\hline NBT & $725 \mathrm{~b}$ & $734 \mathrm{~b}$ & $938 \mathrm{a}$ & $926 \mathrm{a}$ & 58.5 \\
SGR & $1.3 \mathrm{~b}$ & $2.1 \mathrm{~b}$ & $20.1 \mathrm{a}$ & $18.1 \mathrm{a}$ & 5.0 \\
\hline TGR & $8.9 \mathrm{c}$ & $21.4 \mathrm{~b}$ & $78.0 \mathrm{a}$ & $60.9 \mathrm{a}$ & 16.3 \\
\hline LAR & $-16.7 \mathrm{c}$ & $13.1 \mathrm{~b}$ & $32.7 \mathrm{a}$ & $15.3 \mathrm{~b}$ & 10.3 \\
\hline TAR & $-15.9 \mathrm{c}$ & $15.3 \mathrm{~b}$ & $52.8 \mathrm{a}$ & $33.4 \mathrm{~b}$ & 14.6 \\
\hline
\end{tabular}

NBT: number of basal tillers; SGR: stem growth rate; TGR: total growth rate; LAR: leaf accumulation rate; TAR: total accumulation rate; SEM: standard error of the mean; Means followed by the same letter, in the same row, are not significantly different by Tukey's test $(P>0.05)$.

The relative contribution of tiller age category in the canopy was influenced by the time of the year $(P<0.05)$ and the interaction between time of the year and tiller age categories $(P<0.05)$, but did not vary with the fertilization condition $(P>0.05)$ (Figure 2). The proportion of young tillers was lower in winter and early spring, higher in late spring and intermediate in summer. On the other hand, the proportion of old tillers increased from winter to early spring, decreasing during late spring and summer, where it reached the lowest values. As for the proportion of mature tillers, it decreased from winter to late spring, but increased in summer. At all times of the year, the proportion of old tillers was higher than other tiller categories. The percentage of young tillers was lower in winter, while the percentage of mature tillers was lower in late spring. 
The SGR, TGR, LAR and TAR were influenced $(P<0.05)$ by the fertilization condition, by the time of the year (Table 1 ) and by tiller age (Table 2). The SGR (17.3 vs. $9.0 \mathrm{~kg}$ $\mathrm{ha}^{-1}$ day DM), TGR (55.0 vs. $29.5 \mathrm{~kg} \mathrm{ha}^{-1}$ day DM),
LAR (18.9 vs. $3.3 \mathrm{~kg} \mathrm{ha}^{-1}$ day DM) and TAR (32.6 vs. $10.2 \mathrm{~kg} \mathrm{ha}^{-1}$ day DM) of the canopy that received a high fertilizer rate were higher than the canopy managed with low fertilization.

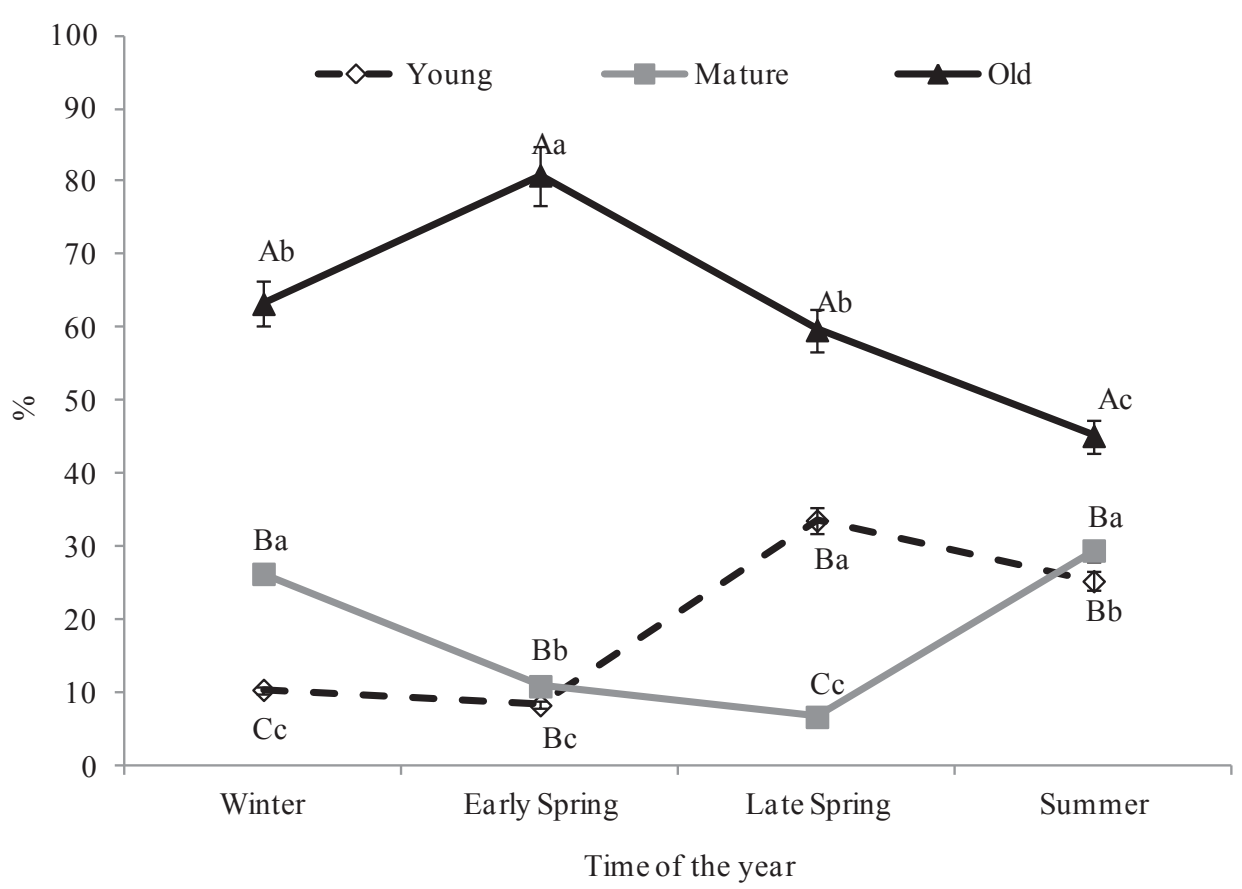

Figure 2. Relative participation (\%) of young, mature and old tillers for total tillers of Marandu palisadegrass canopies in different times of the year. Symbols with the same letter, lowercases compare seasons within the same age, and uppercases compare ages within the same season, are not significantly different by Tukey's test $(P>0.05)$.

\section{Table 2}

Tiller age contribution to herbage accumulation rate of Marandu palisadegrass canopies

\begin{tabular}{ccccc}
\multirow{2}{*}{ Characteristic } & \multicolumn{3}{c}{ Tiller age $\left(\mathrm{kg} \mathrm{ha}^{-1}\right.$ day $\left.^{-1} \mathrm{DM}\right)$} & SEM \\
\cline { 2 - 4 } SGR & Young & Mature & Old & 2.3 \\
TGR & $11.07 \mathrm{ab}$ & $6.12 \mathrm{~b}$ & $14.01 \mathrm{a}$ & 11.6 \\
LAR & $45.46 \mathrm{~b}$ & $20.72 \mathrm{c}$ & $60.66 \mathrm{a}$ & 5.2 \\
TAR & $20.74 \mathrm{a}$ & $2.94 \mathrm{~b}$ & $9.62 \mathrm{~b}$ & 6.6
\end{tabular}

SGR: stem growth rate; TGR: total growth rate; LAR: leaf accumulation rate; TAR: total accumulation rate; SEM: standard error of the mean; Means followed by the same letter, in the same row, are not significantly different by Tukey's test $(P>0.05)$. 
The highest SGR and TGR were registered $(P<0.05)$ in late spring and summer and the lowest rates, during winter and early spring (Table 1). In late spring, the highest values of LAR and TAR were also recorded $(P<0.05)$, while the lowest values occurred in winter, with intermediate values in early spring and summer (Table 1).

Regardless of the fertilization condition, old and young tillers had greater contributions $(P<0.05)$ for the canopy SGR. Old tillers had a greater contribution to the TGR than the other tiller age categories. On the other hand, young tillers presented $(P<0.05)$ a greater contribution to the canopy LAR than other tillers. Young tillers also expressed $(P<0.05)$ a greater contribution to the canopy TAR, compared to mature tillers, but not differing from old tillers (Table 2).
The canopy LGR was influenced $(P<0.05)$ by the fertilization condition, the time of the year and the interaction of these factors with the tiller age category. The LGR was $(P<0.05)$ higher in late spring and summer, intermediate in early spring, and lower in winter (Table 3). When the fertilization effect was detected, the LGR was higher $(P<0.05)$ in the canopy under high fertilizer rate compared to those under low fertiliztion. Among the age categories, the LGR was higher $(P<0.05)$ with high fertilizer in summer for young tillers and in winter for mature tillers. While for old tillers, there was an increase and higher values $(P<0.05)$ with high fertilization in the early and late spring, and also in summer (Table 3 ).

\section{Table 3}

Leaf growth rate for different tiller ages of Marandu palisadegrass canopies under two fertilization conditions in different times of the year

\begin{tabular}{|c|c|c|c|c|c|}
\hline \multirow{2}{*}{$\begin{array}{l}\text { Fertilization } \\
\text { condition }\end{array}$} & \multicolumn{3}{|c|}{ Tiller age (kg ha ${ }^{-1}$ day $^{-1}$ of DM) } & \multirow{2}{*}{ SEM } & \multirow{2}{*}{ Mean } \\
\hline & Young & Mature & Old & & \\
\hline \multicolumn{5}{|c|}{ Winter } & \multirow{3}{*}{$7.5 C^{\prime}$} \\
\hline Low & $2.9 \mathrm{bA}$ & $4.2 \mathrm{bB}$ & $8.5 \mathrm{aB}$ & \multirow{2}{*}{2.1} & \\
\hline High & $3.3 \mathrm{bA}$ & $10.6 \mathrm{aA}$ & 15.7 aA & & \\
\hline \multicolumn{5}{|c|}{ Early spring } & \multirow{3}{*}{$19.3 B^{\prime}$} \\
\hline Low & $7.0 \mathrm{bA}$ & $10.2 \mathrm{bA}$ & $24.8 \mathrm{aB}$ & \multirow{3}{*}{7.6} & \\
\hline High & $10.3 \mathrm{bA}$ & $8.3 \mathrm{bA}$ & $55.1 \mathrm{aA}$ & & \\
\hline \multicolumn{4}{|c|}{ Late spring } & & \multirow{3}{*}{$57.9 A^{\prime}$} \\
\hline Low & $62.1 \mathrm{aA}$ & $12.4 \mathrm{bA}$ & $56.5 \mathrm{aB}$ & \multirow{3}{*}{17.4} & \\
\hline \multirow[t]{2}{*}{ High } & $77.60 \mathrm{bA}$ & $13.1 \mathrm{cA}$ & $125.6 \mathrm{aA}$ & & \\
\hline & & Summer & & & \multirow{3}{*}{$42.8 A^{\prime}$} \\
\hline Low & $33.4 \mathrm{aB}$ & $23.8 \mathrm{aA}$ & $24.3 \mathrm{aB}$ & \multirow{2}{*}{9.2} & \\
\hline High & $78.5 \mathrm{aA}$ & $34.2 \mathrm{bA}$ & $62.8 \mathrm{aA}$ & & \\
\hline
\end{tabular}

Means followed by the same letter, within each season, are not significantly different by Tukey's test ( $P>0.05)$; SEM: standard error of mean; Means followed by the same lowercase, in the same row, and uppercase, in the column, are not significantly different by Tukey's test $(P>0.05)$. Means followed by an uppercase letter plus " ' " compare times of the year and are not significantly different if with the same letter, by Tukey's test $(P>0.05)$. 
The LSR was influenced $(P<0.05)$ by the time of the year and by the interaction between time of the year and tiller age. Old tillers contributed to the highest $(P<0.05)$ canopy LSR in winter, early spring and summer
In late spring, young and old tillers had $(P<0.05)$ greater contribution to the canopy LSR than mature tillers (Table 4). For all tiller age categories, LSR was lower in early spring than in other times of the year (Table 4).

\section{Table 4}

Leaf senescence rate for different tiller ages of Marandu palisadegrass canopies in the times of the year

\begin{tabular}{ccccc} 
Time of year & \multicolumn{3}{c}{ Tiller Age $\left(\mathrm{kg} \mathrm{ha}^{-1}\right.$ day $\left.^{-1} \mathrm{DM}\right)$} & SEM \\
\cline { 2 - 4 } Winter & Young & Mature & Old & 14.2 \\
Early spring & $4.4 \mathrm{cB}$ & $16.8 \mathrm{bA}$ & $51.7 \mathrm{aA}$ & 3.7 \\
Late spring & $1.7 \mathrm{bC}$ & $3.2 \mathrm{bC}$ & $13.6 \mathrm{aB}$ & 10.0 \\
Summer & $30.0 \mathrm{aA}$ & $5.9 \mathrm{bB}$ & $39.7 \mathrm{aA}$ & 7.9
\end{tabular}

SEM: standard error of the mean; Means followed by the same letter, lowercase in the same row, and uppercase in the same column, do not differ from each other by Tukey's test $(P<0.05)$. .

The winter and early spring were the seasons in which the lowest growth rates were found (Tables 1 and 3), due to limiting abiotic factors typical of those seasons (Figure 1). Also, in winter and early spring, characterized by lower rainfall, temperature (Figure $1 \mathrm{~A}$ ) and soil water deficit (Figure 1B), the lowest NBT (Table 1) was registered, due to the reduction in the balance between the tiller appearance and mortality (S. C. Silva et al., 2017). This fact, added to the low growth (Fagundes et al., 2006; Paula et al., 2012) and the high senescence (R. M. Carvalho et al., 2016) of tillers of tropical grasses during the winter, contributed to the low values of canopy growth and accumulation at this time of year (Tables 1 and 3). On the other hand, in late spring and summer, in general, NBT and growth rates and herbage accumulation increased (Tables 1 and 3), as a consequence of the greater availability of growth factors in these times (Figures 1 and 2).
Total and leaf accumulation rates decreased from late spring to summer (Table 1), due to the occurrence of soil water deficit during the summer (Figure 1B). However, SGR did not show this same pattern, probably because of the onset of flowering, which stimulates stem elongation in the summer, as already reported by Paula et al. (2012). These response patterns in growth rates and herbage accumulation throughout the seasons demonstrate the typical seasonal production of Marandu palisadegrass.

In all seasons of the year with lower rainfall and temperature (winter and early spring), tillers survive longer, reaching older age, while the opposite response pattern usually occurs in late spring and summer (Caminha et al., 2010; Sbrissia et al., 2010). For this reason, the proportion of young tillers was lower in winter and early spring, higher 
in late spring and intermediate in summer. The high population of young tillers that appeared in late spring developed up and was classified as mature tillers in the summer (Figure 2). On the other hand, the percentage of old tillers increased from winter to early spring, decreasing during late spring and summer, when reached the lowest values (Figure 2). These response patterns are consistent with seasonal variations in tiller survival registered by Sbrissia et al. (2010) for Marandu palisadegrass. According to these authors, the plants maximize tillering during the summer, which results in more productive and shorter generations. During winter, tiller survival increases, which corresponds to a way of keeping the population stable and guaranteeing persistence in seasons of the year of water shortage and low temperatures, to compensate for the lower tiller appearance rate (Sbrissia et al., 2010).

However, regardless of the time of the year, in all canopies under low or high fertilization, the old tiller was the predominant age category (Figure 2 and 3). This result diverges from Paiva et al. (2011), who reported a predominance of old tillers only from July to December (winter and spring), but in summer, the pastures were mostly made up of young tillers, regardless of nitrogen rates used. It is possible that differences in soil fertility (higher in Paiva et al. (2011), especially regarding the phosphorus and organic matter contents), in addition to differences in climatic conditions explain the differences in results between studies. Moreover, the tiller population renewal is dependent on the defoliation management (Sbrissia et al., 2010); fertilization, mainly nitrogen (Caminha et al., 2010); abiotic factors (Sbrissia et al., 2010); and the interactions between these factors, which cause variations in the growth and tiller renewal in different studies.

The predominance of old tillers in Marandu palisadegrass canopies (Figure 2) indicates that tillers showed great longevity. This is a typical characteristic of plants that have a conservative strategy in the use of resources, that is, this occurs in plants that retain their leaves to preserve nutrients. According to Duchini et al. (2018), plants with a persistence strategy based on prioritizing tiller survival (longevity) are less affected by abiotic stress, and tiller renewal is concentrated or limited at a specific time of the year. In this context, the late spring was the time when the concentration of tiller renewal occurred, which is why the proportion of young tillers increased in canopies (Figure 2). Thus, management practices should ensure tiller appearance during late spring, a time when the Marandu palisadegrass recovered the tiller population density (Table 1).

The high contribution of old tillers to TGR (Table 2) can be attributed to the greater proportion of this tiller age category in the total population density of forage canopies (Figure 2). Likewise, even with a lower individual growth rate (Montagner et al., 2011; Paiva et al., 2011; Barbosa et al., 2012); and less responsive to nitrogen fertilization than young tillers (Paiva et al., 2011), the LGR of old tillers expressed an increase with high fertilization in all times of the year, while for young tillers, this only occurred during the summer (Table 3). This result can be attributed to the higher proportion of old tillers in canopies (Figure 2 ), which was also responsible for the greater contribution of canopy senescence rate, relatively young and mature tillers (Table 4). However, young tillers, although with smaller relative participation in the total population 
density of the canopy, relatively to old tillers (Figure 2), showed the greatest contribution to the LAR of the Marandu palisadegrass canopy (Table 2). This may be explained by three factors: (i) young tillers have a higher growth rate than mature and old tillers (Montagner et al., 2011; Paiva et al., 2011; Barbosa et al., 2012; Alves et al., 2019); (ii) young tillers had a high contribution to the LGR of the canopy in late spring and summer (Table 3), when Marandu palisadegrass concentrated its growth (Table 1 ); (iii) and in winter, early spring and summer, young tillers contributed little to the canopy LSR (Table 4).

With respect to fertilization, it is known that the application of fertilizers, especially nitrogen fertilizers, increases the leaf appearance rate in tropical forage grasses (Pereira et al., 2015). With the appearance of a new leaf, a new axillary bud also appears, with the potential to develop into tillers. In this sense, the site filling, which corresponds to the proportion of existing axillary buds that develop into new tillers (Skinner \& Nelson, 1995), may increase in pastures fertilized with nitrogen, as long as the pasture LAI is low (Lemaire, 2001). This justifies the greater number of basal tillers in canopies under high fertilization, compared to those managed with low fertilization. This can also be explained, considering that both the appearance and mortality of tiller increase with the use of fertilizers, especially nitrogen. Nevertheless, in general, the increase in appearance is more accentuated than tiller mortality (Moraes et al., 2006; Caminha et al., 2010). With this, there is an increase in the number of tillers in the fertilized pasture. Furthermore, the stimulation of nitrogen to the growth of individual tillers (Paciullo et al., 2017), also explains the higher growth and herbage accumulation rates in canopies under high fertilization rates.

The application of higher doses of fertilizers did not change the relative participation of tillers in the canopy. This result differs from that observed by Paiva et al. (2011), who found that tiller renewal had a greater magnitude and, as a result, the percentage of young tillers increased more intensely during spring and summer in Marandu palisadegrass pastures fertilized with 300 and $450 \mathrm{~kg} \mathrm{~N} \mathrm{ha}^{-1}$, in comparison to those not fertilized or that received $150 \mathrm{~kg} \mathrm{~N} \mathrm{ha}^{-1}$. Even without changing the proportion of young, mature and old tillers, nitrogen and phosphate fertilization increased the total number of tillers in the canopy (Figure 3). In this way, in late spring and summer, the number of young tillers was 31 and 106\% higher, respectively, in the canopy under high fertilization, compared to that under low fertilization. Thus, the condition of high fertilization generates canopies with a greater number of young tillers, which can contribute to greater growth and herbage accumulation, as already discussed. 


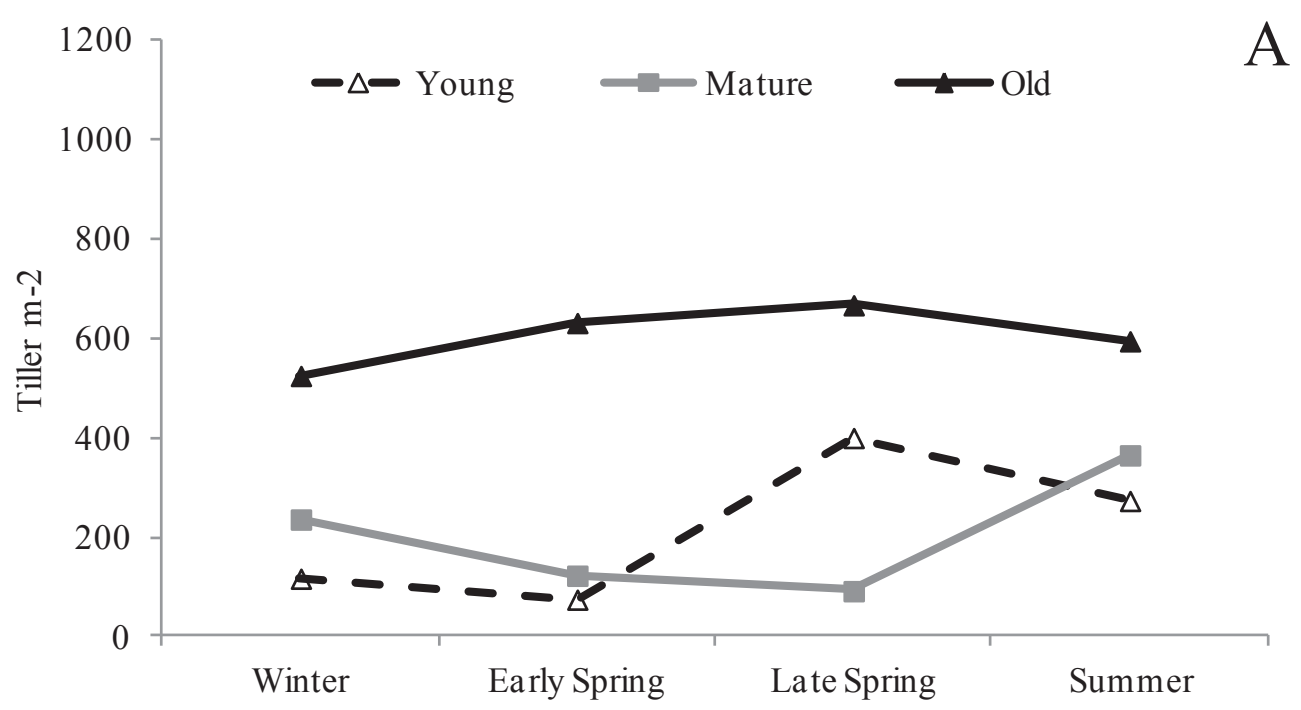

Time of the year

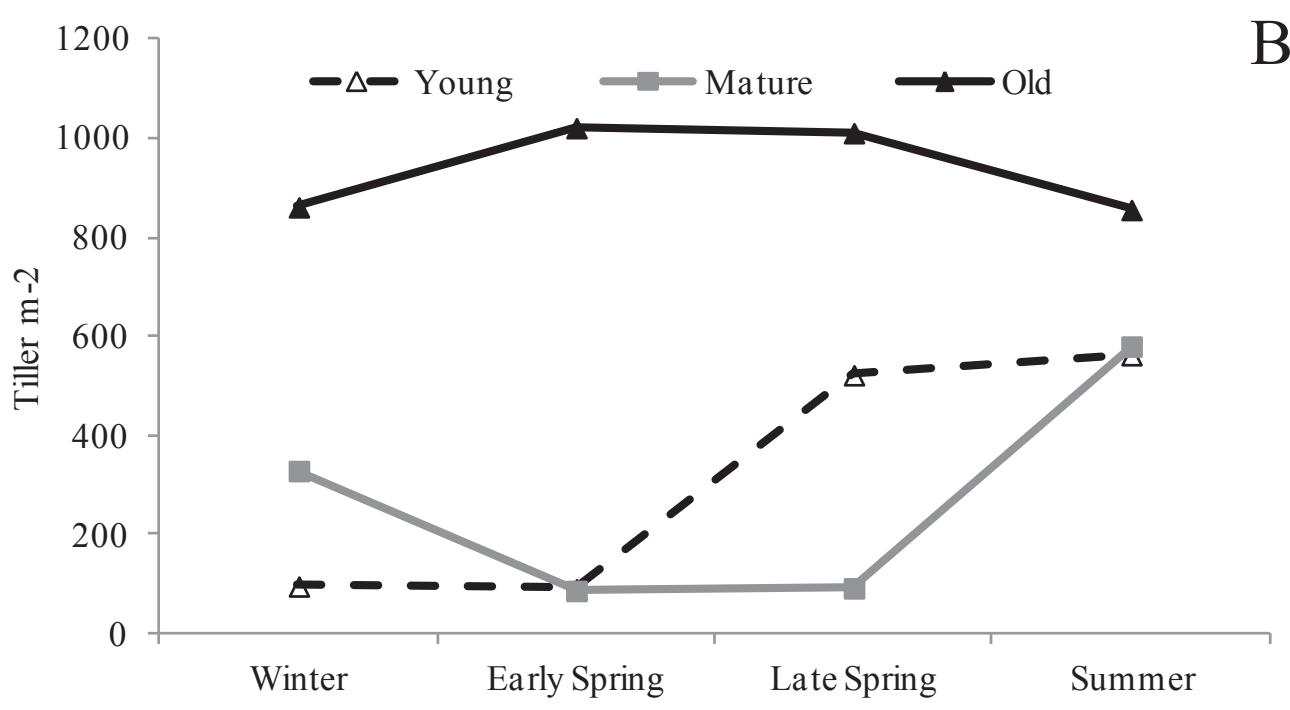

Time of the year

Figure 3. Young, mature and old tillers $\mathrm{m}^{-2}$ in different times of the year on Marandu palisadegrass under low (A) and high (B) fertilization condition.

Based on our results, our hypotheses were partially accepted. The application of higher doses of nitrogen and phosphate fertilizers increased the total number of tillers and the herbage accumulation, but did not influence the proportion of young tillers in the Marandu palisadegrass canopy.
Contrary to what was hypothesized, old tillers predominated in the canopy at all times of the year. On the other hand, corroborating our hypothesis and despite the high relative participation of old tillers in the canopies, the times of the year with the highest occurrence of young tillers, were when there was the 
greatest canopy herbage accumulation. In this way, in all times of the year, the old tiller category is predominant in the canopy and has a great contribution to growth and senescence rates. During growing seasons, the old and young tiller categories are responsible for forage accumulation rates, but in different ways. The old tiller category participates with higher plant population density and the young tiller category, probably, with higher individual growth rates.

\section{Conclusion}

The old tillers category is the major category in canopy during all year, and has the higher contribution over growth and senescence rates. While old tillers are in higher numbers in the canopy, the young tillers has higher growth rates.

There is a strong and positive association between the occurrence of young tillers and the high levels of herbage accumulation in the Marandu palisadegrass canopy.

\section{References}

Allen, V. G., Batello, C., Berretta, E. J., Hodgson, J., Kothmann, M., LI, X.,... Sanderson, M. (2011). An international terminology for grazing lands and grazing animals. Grass and Forage Science, 66(1), 2-28. doi: 10.1111/j.1365-2494.2010.00780.x

Alvares, C. A., Stape, J. L., Sentelhas, P. C., Gonçalves, J. L. M., \& Sparovek, G. (2013). Köppen's climate classification map for Brazil. Meteorologische Zeitschrift, 22(6), 711-728. doi: 10.1127/0941-2948/2013/ 0507
Alves, L. C., Santos, M. E. R., Pereira, L. E. T., Carvalho, A. N., Rocha, G. O., Carvalho, B. H. R.,... Avila, A. B. (2019). Morphogenesis of age groups of Marandu palisade grass tillers deferred and fertilised with nitrogen. Semina: Ciências Agrárias, 40(6), 26832692. doi: 10.5433/1679-0359.2019v40n $6 \mathrm{p} 2683$

Barbosa, R. A., Nascimento, D., Jr., Vilela, H. H., Sousa, B. M. L., Silva, S. C., Euclides, V. P. B., \& Silveira, M. C. T. (2012). Morphogenetic and structural characteristics of guinea grass tillers at different ages under intermittent stocking. Revista Brasileira de Zootecnia, 41(7), 1583-1588. doi:10.1590/ S1516-35982012000700005

Bircham, J. S., \& Hodgson, J. (1983). The influence of sward condition on rates of herbage growth and senescence in mixed swards under continuous stocking management. Grass and Forage Science, 38(4), 323-331. doi: 10.1111/j.1365-2494. 1983.tb01656.x

Caminha, F. O., Silva, S. C., Paiva, A. J., Pereira, L. E. T., Mesquita, P., \& Guarda, V. D. (2010). Stability of tiller population of continuously stocked marandu Palisade grass fertilized with nitrogen. Pesquisa Agropecuária Brasileira, 45(2), 213-220. doi: 10.1590/ S0100-204X2010000200013

Carvalho, A. N. D., Alves, L. C., Santos, M. E. R., Rocha, G. D. O., Rodrigues, P. H. M., \& Carvalho, B. H. R. (2019). Como a idade do perfilho e a adubação nitrogenada modificam as características estruturais do capim-marandu diferido? Ciência Animal Brasileira, 20, 1-12. doi: 10.1590/1809-6891v20e-44460

Carvalho, R. M., Santos, M. E. R., Carvalho, B. H. R., Carvalho, C. R. A., Silveira, J. P. F., \& Costa, L. K. P. (2016). Morphogenesis of marandu palisade grass next or distant 
from the catte feces during the seasons. Semina: Ciências Agrárias, 37(5), 32313242. doi: 10.5433/1679-0359.2016v37n $5 \mathrm{p} 3231$

Costa, L. K. P., Santos, M. E. R., Silva, G. P., Carvalho, B. H. R., Pessoa, D. D., Galzerano, L., \& Silva, N. A. M. (2016). Reduction of sward height in the fall/winter as strategy to optimize tillering in Urochloa brizantha syn. Brachiaria brizantha. Archivos de Zootecnia, 65(252), 499-506. doi: 10.21071/az.v65i 252.1917

Difante, G. D. S., Nascimento, D. D., Jr., Silva, S. C. D., Euclides, V. P. B., Montagner, D. B., Silveira, M. C. T. D., \& Pena, K. D. S. (2011). Características morfogênicas e estruturais do capim-marandu submetido a combinações de alturas e intervalos de corte. Revista Brasileira de Zootecnia, 40(5), 955-963. doi: 10.1590/S1516-35 982011000500003

Duchini, P. G., Guzatti, G. C., Echeverria, J. R., Américo, L. F., \& Sbrissia, A. F. (2018). Experimental evidence that the perennial grass persistence pathway is linked to plant growth strategy. PLOS ONE, 13(11), 1-15. doi: 10.1371/journal.pone.0207360

Fagundes, J. L., Fonseca, D. M., Mistura, C., Moraes, R. V., Vitor, C. M. T., Gomide, J. A.,... Casagrande, D. R. (2006). Características morfogências e estruturais do capimbraquiaria em pastagem adubada com nitrogênio avaliadas nas quatro estações do ano. Revista Brasileira de Zootecnia, 35(1), 21-29. doi: 10.1590/S1516-3598 2006000100003

Gastal, F., \& Lemaire, G. (2015). Defoliation, shoot plasticity, sward structure and herbage utilization in pasture: Review of the underlying ecophysiological processes. Agriculture, 5(4), 1146-1171. doi: 10.3390/agriculture5041146
Gimenes, F. M. D. A., Silva, S. C. D., Fialho, C. A., Gomes, M. B., Berndt, A., Gerdes, L., \& Colozza, M. T. (2011). Ganho de peso e produtividade animal em capimmarandu sob pastejo rotativo e adubação nitrogenada. Pesquisa Agropecuária Brasileira, 46(7), 751-759. doi: 10.1590/ S1806-66902013000100023

Lemaire, G. (2001). Ecophysiology of grasslands: dynamic aspects of forage plant populations in grazed swards. Proceedings of International Grassland Congress, São Pedro, SP, Brasil, 19.

Lemaire, G., \& Chapman, D. F. (1996). Tissue fluxes in grazing plant communities. In J. Hodgson, \& A. W. Illius (Eds.), The ecology and management of grazing systems (pp. 3-36). Wallingford, UK: CAB International.

Martins, C. D. M., Schmitt, D., Duchini, P. G., Miqueloto, T., \& Sbrissia, A. F. (2021). Defoliation intensity and leaf area index recovery in defoliated swards: implications for forage accumulation. Scientia Agricola, 78(2), 2019-0095. doi: 10.1590/1678-99 2X-2019-0095

Montagner, D. B., Nascimento, D., Jr., Sousa, B. M. L., Vilela, H. H., Euclides, V. P. B., Silva, S. C..... Carloto, M. N. (2011). Morphogenetic and structural characteristics of tillers of guinea grass of different age and grazing severities. Revista Brasileira de Zootecnia, 40(10), 2105-2110. doi: 10.1590/S151635982011001000006

Moraes, R. V., Fonseca, D. M., Nascimento, D., Jr., Ribeiro, J. I., Jr., Fagundes, J. L., Moreira, L. M.,... Martuscello, J. A. (2006). Demografia de perfilhos basilares em pastagem de Brachiaria decumbens adubada com nitrogênio. Revista Brasileira de Zootecnia, 35(2), 380-388. doi: 10.1590/S1516-3598 2006000200007 
Paciullo, D. S. C., Gomide, C. A. M., Castro, C. R. T., Maurício, R. M., Fernandes, P. B., \& Morenz, M. J. F. (2017). Morphogenesis, biomass and nutritive value of Panicum maximum under different shade levels and fertilizer nitrogen rates. Grass and Forage Science, 72(3), 590-600. doi: 10.1111/gfs.12264

Paiva, A. J., Pereira, L. E. T., Silva, S. C., \& Dias, R. A. P. (2015). Identification of tiller age categories based on morphogenetic responses of continuously stocked marandu palisade grass fertilised with nitrogen. Ciência Rural, 45(5), 867-870. doi: 10.1590/0103-8478cr20120738

Paiva, A. J., Silva, C. S., Pereira, L. E. T., Caminha, F. O., Pereira, P. M., \& Guarda, V. D. (2011). Morphogenesis on age categories of tillers in marandu palisadegrass. Scientia Agricola, 68(6), 626-631. doi: 10.1590/ S0103-90162011000600003

Paiva, A. J., Silva, S. C. da, Pereira, L. E. T., Guarda, V. D., Pereira, P. M., \& Caminha, F. O. (2012). Structural characteristics of tiller age categories of continuously stocked marandu palisade grass swards fertilized with nitrogen. Revista Brasileira de Zootecnia, 41(1), 24-29. doi: 10.1590/ S1516-35982012000100004

Parsons, A. J., \& Penning, P. D. (1988). The effect of the duration of regrowth on photosynthesis, leaf death and the average rate of growth in a rotationally grazed swar. Grass and Forage Science, 43(1), 15-27. doi: 10.1111/j.1365-2494.1988.tb02137.x

Patês, N. M. S., Pires, A. J. V., Silva, C. C. F., Santos, L. C., Carvalho, G. G. P., \& Freire, M. A. L. (2007). Características morfogênicas e estruturais do capimtanzânia submetido a doses de fósforo e nitrogênio. Revista Brasileira de Zootecnia, 36(6), 1736-1741. doi: 10.1590/S1516-35 982007000800005
Paula, C. C. L., Euclides, V. P. B., Lempp, B., Barbosa, R. A., Montagner, D. B., \& Carloto, M. N. (2012). Acúmulo de forragem, características morfogênicas e estruturais do capim-marandu sob alturas de pastejo. Ciência Rural, 42(11), 2059-2065. doi: 10.1590/S0103-84782012005000084

Pereira, L. E. T., Paiva, A. J., Geremia, E. V., \& Silva, S. C. da. (2013). Components of herbage accumulation in elephant grass cvar Napier subjected to strategies of intermittent stocking management. Journal of Agricultural Science, 152(6), 954-966. doi: $10.1017 / S 0021859613000695$

Pereira, L. E. T., Paiva, A. J., Guarda, V. D., Pereira, P. M., Caminha, F. O., \& Silva, S. C. da. (2015). Herbage utilisation efficiency of continuously stocked marandu palisade grass subjected to nitrogen fertilisation. Scientia Agricola, 72(2), 114-123. doi: 10. 1590/0103-9016-2014-0013

Pessoa, D. D., Cardoso, R. C., Santos, M. E. R., Carvalho, B. H. R., Silva, G. P., \& Silva, N. A. M. (2016). Tillering of Marandu palisadegrass maintained at fixed or variable heights throughout the year. Tropical Grasslands - Forrajes Tropicales, 4(2), 101-111. doi: $10.17138 / \operatorname{tgft}(4) 101-111$

Santos, H. G., Jacomine, P. K. T., Anjos, L. H. C., Oliveira, V. A., Lumbreras, J. F., Coelho, M. R.,... Cunha, T. J. F. (Eds.) (2006). Sistema brasileiro de classificação de solos. Rio de Janeiro: EMBRAPA Solos.

Santos, M. E. R., Avila, A. B., Carvalho, A. N., Rocha, G. O., Van Cleef, F. S., Segatto, B. N.,... Pereira, R. S. (2018). Strategies of shortening Marandu palisade grass in the beginning of the deferment period and its effects on the tillering. Semina: Ciências Agrárias, 39(4), 1617-1626. doi: 10.5433/1679-0359.2018 v39n4p1617 
Santos, M. E. R., Carvalho, B. H. R., Carvalho, A. N., Rocha, G. O., Van Cleef, F. O. S., Queiroz, G. J. S.,... Carmo, L. L. S. (2020). Number and morphology of tiller age groups during summer in Marandu palisadegrass pastures previously used under deferred grazing. Bioscience Journal, 36(1), 173-182. doi: 10.14393/ BJ-v36n1a2020-42215

Santos, M. E. R., Fonseca, D. M., \& Gomes, V. M. (2013). Forage accumulation in brachiaria grass under continuous grazing with single or variable height during the seasons of the year. Revista Brasileira de Zootecnia, 42(5), 312-318. doi: 10.1590/ S1516-35982013000500002

Santos, M. E. R., Simplício, M. G., Silva, G. P., Oliveira, H. A., Costa, L. K. P., \& Sousa, D. O. C. (2017). Reduction of sward height in the fall and winter as a strategy to improve the structure of marandu palisadegrass (Urochloa brizantha syn. Brachiaria brizantha cv. Marandu). Tropical Grasslands-Forrajes Tropicales, 5(3), 143152. doi: $10.17138 / \operatorname{tgft}(5) 143-152$

Sbrissia, A. F., Schmitt, D., Duchini, P. G., \& Silva, S. C. da. (2020). Unravelling the relationship between a seasonal environment and the dynamics of forage growth in grazed swards. Journal of Agronomy an Crop Science, 1(5), 1-8. doi: 10.1111/jac.12402

Sbrissia, A. F., Silva, S. C., Sarmento, D. O. L., Molan, L. K., Andrade, F. M. E., Gonçalves, A. C., \& Lupinacci, A. V. (2010). Tillering dynamics in palisadegrass swards continuously stocked by cattle. Plant Ecology, 206, 349-359. doi: 10.1007/s11 258-009-9647-7

Silva, D. R. G., Costa, K. A. D. P., Faquin, V., Oliveira, I. P. D., \& Bernardes, T. F. (2013). Doses e fontes de nitrogênio na recuperação das características estruturais e produtivas do capim-marandu. Revista Ciência Agronômica, 44(1), 184-191. doi: 10.1590/ S1806-66902013000100023

Silva, S. C., Chiavegato, M. B., Pena, K. S., Silveira, M. C. T., Barbero, L. M., Junior S. J. S., Rodrigues, C. S., Limão, V.A. \& Pereira, L. E. T. (2017). Tillering dynamics of Mulato grass subjected to strategies of rotational grazing management. Journal of Agricultural Science, 155(7), 1-11. doi 10.1017/S0021859617000223

Silva, S. C., Sbrissia, A., \& Pereira, L. (2015). Ecophysiology of C4 forage grasses understanding plant growth for optimising their use and management. Agriculture, 5(3), 598-625. doi: 10.3390/agriculture50 30598

Skinner, R. H., \& Nelson, C. J. (1995). Elongation of the grass leaf and its relationship to the phyllochron. Crop Science, 35(1), 4-10. doi: 10.2135/cropci1995.0011183Х0035 $00010002 x$

Sousa, B. M. L., Nascimento, D., Jr., Monteiro, H. C. F., Silva, S. C. da, Vilela, H. H., Silveira, M. C. T.,... Sbrissia, A. F. (2013). Dynamics of forage accumulation in Elephant grass subjected to rotational grazing intensities. Revista Brasileira de Zootecnia, 42(9), 629-638. doi: 10.1590/S1516-35982013 000900004

Sousa, B. M. L., Nascimento, D., Jr., Silva, S. C. da, Rodrigues, C. S., Monteiro, H. C. F., Silva, S. C.,... Sbrissia, A. F. (2011). Morphogenetic and structural characteristics of Xaraes palisadegrass submitted to cutting heights. Revista Brasileira de Zootecnia, 40(1), 53-59. doi: 10.1590/S1516-3598 2011000100008

Terra, S. R., Gimenes, F. M. A., Giacomini, A. A., Gerdes, L., Manco, M. X., Mattos, W. T., \& Batista, K. (2020). Seasonal alteration in sward height of Marandu palisade grass 
(Brachiaria brizantha) pastures managed by continuous grazing interferes with forage production. Crop and Pasture Science, 71(3), 1-9. doi: 10.1071/CP19156

Thornthwaite, C. W., \& Mather, J. R. (Eds.) (1955). The water balance. Publications in Climatology. New Jersey: Drexel Institute of Technology. Retrieved from https:// oregondigital.org/catalog/oregondigital: df70pr001\#page/1/mode/1up
Wolfinger, R. (1993). Covariance structure selection in general mixed models. Communications in Statistics Simulation, 22(4), 1079-1106. doi: 10.10 80/03610919308813143 